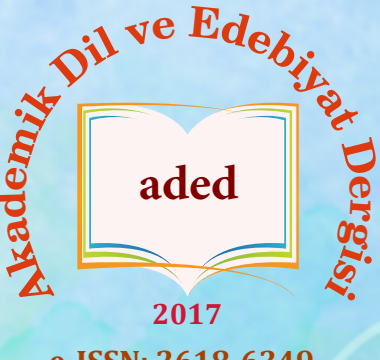

Akademik Dil ve Edebiyat Dergisi Academic Journal of Language and Literature Cilt/Volume: 3, Sayı/Issue: 3, (Aralık/December 2019)

e-ISSN: 2618-6349

\title{
Mizaha Tasavvufla Dokunmak: Nasreddin Hoca Fıkralarının Şerhinde Dinî ve Tasavvufî Söyleyişler
}

Touching to Humour with Myticism: The Religious and Mystical Usages in The Gloss of Nasreddin Hodja's Jokes

\section{Büşra KARASU*}

${ }^{\star}$ Araş. Gör., Ankara Hacı Bayram Veli Üniversitesi

e-mail : bussradinc@gmail.com

Araştırma Makalesi / Research Article DOI: https://doi.org/10.34083/akaded.623644

Sorumlu Yazar/Corresponding Author Büşra Karasu, Ankara Hacı Bayram Veli Üniversitesi, Edebiyat Fakültesi, Ankara/Türkiye

ORCID : 0000-0003-3147-237X

Geliş Tarihi/Received : 28.09.2019

Kabul Tarihi/Accepted : 15.11.2019

\section{Atıf / Citation}

Karasu, Büşra (2019). Mizaha Tasavvufla

Dokunmak: Nasreddin Hoca Fıkralarının Şerhinde Dinî ve Tasavvufi Söyleyişler.

Akademik Dil ve Edebiyat Dergisi, 3 (3), 334-345.

DOI: 10.34083 /akaded.623644

\section{SCREENED BY}

Öz

Nasreddin Hoca, Türk halkının mizah kabiliyetini ortaya koyan, somut olmayan kültürel mirasımız içerisinde yer alan en önemli fikra tiplerindendir. Anadolu halkının zekâsını, hazırcevaplığını ve aklını temsil eden Hoca halk tarafından çok sevilmiş ve sahiplenilmiştir. Bu sayede bilge Hoca tipi yüzyıllar boyunca Anadolu halkının dimağında yaşamış ve onun kimliği fikraları vasıtasıyla nesilden nesile aktarılmıştır. Bunda halkın Hoca'yı bilge bir tip olarak kabul etmesi, onun hikmetli sözlerinden faydalanmak istemeleri etkili olmuştur.

Halkın bu kadar sahiplendiği Nasreddin Hoca'nın esasında doğum ve ölüm tarihi, yaşadığı dönem, yer gibi bilgiler tam olarak bilinmemektedir. Bu konuda bazı bilgiler olsa da bunların hiçbiri net değildir. Yalnızca onun hakkındaki birtakım rivayetler ve akrabalarından kalanlar onun yaşamış olduğu dönem hakkında bizlere birtakım bilgiler sunmaktadır.

Fıkralarda Hoca'nın yanı sıra eşinin, eşeğinin, mahalle çocuklarının, cami cemaatinin, şehir esnafının ve bunun gibi birçok kişi ile zümrenin yer aldığı Nasreddin Hoca nükteleri kimi zaman eğlendirici, kimi zaman ögüt verici, kimi zaman da iğneleyicidir. Halk arasında bu kadar yayılmış, gerek yurt dışında gerekse de yurt içinde pek çok araştırmaya konu edilmiş olan fikralar hakkında çok sayıda çalışma yapılmıştır. Bu çalışmalar arasında şerhler de yer almaktadır. Şair Burhâneddin de bahsi geçen bu türde bir eser kaleme almış, eserini tasavvufî bir bakış açısıyla oluşturmuştur. Şârihin şerh çalışmasının bu niteliğinden dolayı eserde dinî ve tasavvufî birtakım söyleyişler mevcuttur ve bunlar bazı kaynaklara dayanmaktadır. Çalışmamızda da bu konu irdelenerek Şair Burhâneddin'in Nasreddin Hoca'nın fikralarını şerh ettiği eserindeki dinî ve tasavvufî söyleyişler üzerinde durulacak, bunların kaynakları açıklanacak ve kaynak noktasında bir tasnif çalışmasına gidilecektir. Yanı sıra bir lügatçe ile eserdeki tasavvufî terimler üzerinde durulacaktır.

Anahtar Kelimeler: Nasreddin Hoca, tasavvuf, somut olmayan kültürel miras, şerh, terim

\begin{abstract}
Nasreddin Hoca is one of the most important people who reveal the humour talent of Turks and takes part our intangible cultural heritage. Hodja who represents Anatolian people's intelligence, repartee and wisdom was loved and embraced by people. Because of this the type of wise Hodja live in the mind of Anatolian people and his identity was transfered from one generation to another via his jokes. In this, people's accepting Hodja as a wise type, and desiring utilise his erudite words.
\end{abstract}

Actually it isn't known Nasreddin Hodja's dates of birth and death, period and place. Although there is knowledge in this subject none of these are clear. Only some rumors about him and rests from his relatives give some information us about Nasreddin Hodja's life.

Nasreddin Hodja's jokes which include Hodja, his wife, donkey, children of the neighborhood, community of mosque, artisans and the other groups sometimes are entertaining, sometimes didatical and sometimes acrimonious. The jokes of Hodja became popular among people and there are many searchs about them. "Serh"s (explanations about jokes) take part among them. Sair Burhaneddin had written a work in this mentioned genre. He created his work with mystical perspective, too. Thereby the serh of commentator's this feature there are religious and mystical usages in work and these are based on some sources. Being examined this subject, in our study it will be urged upon religious and sufistic usages in Şair Burhaneddin's work which he expounded Nasreddin Hodja's jokes. Their sources will be explained, and made a classification. Besides Islamic mystical terms which take part in Şair Burhaneddin's work will be given with a glossary list.

Key Words: Nasreddin Hodja, jokes, Islamic myticism, intangible cultural heritage, gloss 


\section{Giriş}

Anadolu halk anlatılarında “Mevlana ve Yunus Emre 'gönlün', Nasreddin Hoca da 'aklın' sembolü olarak Anadolu'da Türk halk felsefesinin temelini oluşturan 'akıl-gönül' birliğini yaratmışlardır." (Özdemir, 2010: 28) Bu minvalde değerlendirilen Nasreddin Hoca'nın fikraları hemen hemen her yüzyılda ilgi görmüş ve bunlar üzerine çalışmalar yapılmıştır. Bu konuda eser vermiş isimlerden biri de Nasreddin Hoca fikralarını dinî, ahlakî ve tasavvufî bir nazarla şerh etmiş olan Şair Burhaneddin'dir. O, türünün önemli örneklerinden olan bu eserine kendi dünya görüşlerini ve Mevlevilik anlayışını yansıtmıştır.

Çalışmamızda eserin bu hususiyetleri göz önünde bulundurularak önce eserin içeriğinden bahsedilecek, ardından eserde geçen dinî ve tasavvufî söyleyişler tespit edilecek ve bunlar kaynaklarına göre sınıflandırılacaktır.

\section{Şair Burhâneddin'in Nasreddin Hoca'nın Fıkralarını Şerh Eden Eseri ve Eserin Muhtevası}

Kendisini "Es-Seyyid Burhaneddin ibn-i Mevlânâ" olarak tanıtan, Mevlana soyundan geldiği ve Mevlevi olduğu araştırmacılar tarafından belirtilen Şair Burhaneddin'in (Türkmen: 2013: 58-59) kendi açıklamalarına, bilgi birikimine ve olayları yorumlama biçimine göre oluşturmuş olduğu şerhleri tasavvufî ve dinî niteliklidir. Kültürel belleğimizde çok mühim bir yeri olan Hoca'nın zekâsının, hazırcevap oluşunun, meraklı ve ögüt verici niteliklerinin göze çarptığı, toplamda 121 fikranın yer aldığı bu eserde şair Burhâneddin fikraları latife olarak adlandırılmış. Şerh kısımlarına ise "yani" ifadesiyle geçmiştir.

Eser öncelikle "Râviyân-1 ahbâr ve nâkılân-1 âsâr-1 rûzigâr şöyle rivâyet ederler ki" (Halıcı: 2017: 7) girişiyle başlamakta, daha sonra Hoca'nın bir fikrasına yer verilmektedir. Eserin sonunda ise;

"Şârihül-kitab-1 Hâce-i Nasreddin

Es-Seyyid Burhaneddin ibn-i Mevlânâ

Fi 25 Cumadi'l-ahire Sene 1306

Fi 15 Şubat sene 1304

Harrerehu el-müznib Osman el-Hamdî es-

Sillevî ibn Ahmedî’ş-Şükrî gafere lehu veli-ebeveyhi” (Halıcı: 2017: 91)

(Nasreddin Hoca kitabının şârihi Mevlana oğlu Seyyid Burhâneddin

25 Cemaziyelevvel 1306, 15 Şubat 1304.

(Bu kitabı) -Allah kendisine ve ailesine merhamet etsin- Ahmedi’ş-Şükrî oğlu, günahkâr, Silleli Osman el-Hamdî yazdı.)

kaydı yer almaktadır.

"Kendi tarzında bilinen ilk şerh" (Türkmen 2013: 72) olan ve makalemizde Feyzi Halıcı'nın çalışmasını esas aldığımız eser, dil hususiyetleri bakımından incelenecek olursa birtakım özellikler göze çarpar. Bunlardan fikra ve şerhlerin incelenmesi meselesinde değinilebilecek en önemli hususiyetlerden biri şudur: Eserde Nasreddin Hoca'dan nakledilen fikralar sade bir dille, ağır ve ağdalı ifadeler yer almadan verilmiştir. Fakat bunun yanında şârih "yani” ifadesiyle geçtiği şerh bölümlerinde Arapça - Farsça sözcükler ve terimlerle örülü nispeten daha ağır bir dil kullanmıştır. Bunun sebebi, fikraların halk arasında yaygınlık kazanmış olması dolayısıyla dilinin sade olması ve şerh kısımlarında tasavvufî ve dinî terimler ile açılamaların tercih edilmiş olmasıdır. 
Eserde şerhi yapılan fikraların ortak özelliği, dinî veya tasavvufî açıklamalara uygun oluşudur. Seçerek eserine almış olduğu fikraların bahsi geçen bu özelliğinden dolayı Şair Burhâneddin, şerhleri tasavvufî bir nazarla yorumlama imkânı bulmuştur. Bunu yaparken bir yandan olayları tasavvufî açıdan ele almış, bir yandan da kullanmış olduğu terimsel ifadelerle bu anlatımı pekiştirmiştir.

\section{Eserin Şerh Kısmında Dinî-Tasavvufî Anlatımlar ve Kaynakları}

\section{Kaynağı Hadis veya Hadis Olduğu Rivayet Edilen Sözler Olanlar}

Ölmeden önce ölme fikri ehl-i kuburdan olmak:

"Ölmezden evvel ölüp bu elbise-i fahireden soyunup kefeninizi boynunuza takıp" (Latife 6) (Halıc1: 2017: 12)

"Şu dünya endişesinden ve iyâl evlat kaygısından ihtifâ mu’tekif olun belki ölmeden evvel ölüp mûtu kabl en temûtu sırrına erişin, demeği tefhim eder." (Latife 108)

Kaynak: “Ölmeden önce ölünüz” hadisi.

"Nefsini bilen Rabbini dahi bilir" düsturu:

"Kendini kendinde ara kendine himmetiñ 'âlî olsun. Nefsini bilen, Rabbini dahi bilir. Ok yay gibi olan mücahede ile nefsinizi zebun edip tevhid ve tefekkürle kendini bulup aklın başına alıp mühlikeye uğrama, demeyi tefhim eder." (Latife 75) (Halıc1: 2017: 61)

Kaynak: "Kendini bilen Rabbini bilir" hadisi.

"Kişi sevdiğiyle beraberdir" hadisi:

"Mahbûbunuza vasıl olmak istersiniz aç ve üryan olarak riyazet arabasına süvar olup mahbûb-1 Hüdâ'ya vâsıl ve nâil olun. Zira kişi sevdiğini daima zikredip yoluna canını feda eder demeyi, tefhim eder." (Latife 89) (Halıc1: 2017: 70)

Kaynak: "Kişi sevdiğiyle beraberdir." (1)

Çocuklara merhamet ve şefkat gösterilmesi gerektiği:

"Bazı kimseden bâhusûs etfalden sürç-i lisan vâkî olursa tevbih etmeyin. Belki redd-i leyyin ile kendisini ikâz ederek hoş hal üzere nasihat edip kendüye merhamet ve şefkatinizi diriğ etmeyin, deyu tarif buyururlar." (Latife 115) (Halıc1: 2017: 86)

Kaynak: Ebû Hüreyre (ra) anlatıyor: "Resûlullah (sav) (torunu) Hasan b. Ali'yi öptü. O sırada yanında Akra' b. Hâbis et-Temîmî oturmaktaydı. Akra' şöyle dedi: 'Benim on çocuğum var ama hiçbirini öpmüş değilim.' Bunun üzerine Resûlullah (sav) ona baktı ve ardından şöyle buyurdu: "Merhamet etmeyene merhamet edilmez!" (2)

\section{Kaynağı Kur’an-1 Kerim Olanlar}

Mümin olarak her zaman korku ile ümit arasında olmak; "beyne'l-havf u recâ":

"Rizâ’ullah ve mağfiret talebiyle -havf u recâda bulunarak pul gibi olan 'ameliñize mağrûr ve istinâd etmek câ' iz olamıyacağını tarif buyururlar.” (Latife 14) (Halıcı: 2017: 17)

Kaynak: "Korkuyla ve umutla Rablerine yalvarmak üzere (ibadet ettikleri için), vücutları yataklardan uzak kalır ve kendilerine verdiğimiz rızıktan Allah yolunda harcarlar." (Secde suresi, 16. ayet) (Türkiye Diyanet Vakfı Kur'ân-1 Kerîm Açılamalı Meâli, 2013: 406) (3) 
"Her şerde bir hayır vardır” anlayışı:

"Bu dünya makûsdur bazı sureta ziyan görülen şeyin akabinde dünya ve ahiretçe de faidesi hiss olunur." (Latife 12) (Halıc1: 2017: 16)

Kaynak: “... Sizin için daha hayırlı olduğu halde bir şeyi sevmemeniz mümkündür. Sizin için daha kötü olduğu halde bir şeyi sevmeniz de mümkündür. Allah bilir, siz bilmezsiniz." (Bakara Suresi, 216. ayet) (Türkiye Diyanet Vakfı Kur'ân-1 Kerîm Açıklamalı Meâli, 2013: 34)

Evlat ve malın aslında fitne olduğu, çocuklara ilim ve irfan öğretilmesi gerektiği:

"Ruh bizde emanettir. Nefsi üzerine galip eyleme mal ve evlâdınız dahi fitnedir. Yarın malınıza varis olup üzerine yestehledikten sonra belki sinlerinize dahi yaparlar. Hal-i sthhatinizde evlâtlarınıza ilm ü irfan öğretip âlim ve sâlih oldukları halde hidayette olup ba'de-mâ duâ-i hayr ile yâd etmelerini, tenbih eder." (Latife 74) (Halıc1: 2017: 60-61)

Kaynak: "Biliniz ki mallarınız ve çocuklarınız birer imtihan sebebidir ve büyük mükâfat Allah'ın katındadır." (Enfâl suresi, 28. ayet) (Türkiye Diyanet Vakfı Kur’ân-ı Kerîm Açıklamalı Meâli, 2013: 169)

Nefsi şımartmamak için çok yiyip içmemek gerektiği:

"Nefsinizi öyle tatlı tuzlu ta'âmlar ile besleyip azdırmayınız. Daima perhiz üzere olup bir hamir şurbasına kanaat edip nefsinizi zebûn edin Eğerçi böyle etmezseniz şeytan sizi yoldan çıkarıp imanınızı almağa tama' eder demeği tefhim eder.” (Latife 83) (Halıcı: 2017: 66)

Kaynak: "Ey Âdem oğulları! Her secde edişinizde güzel elbiselerinizi giyin; yeyin, için, fakat israf etmeyin; çünkü Allah israf edenleri sevmez." (A'raf suresi, 31. ayet) (Türkiye Diyanet Vakfı Kur'ân-1 Kerîm Açıklamalı Meâli, 2013: 145)

Mal ve ilim ile mağrur olmayıp Hakk’a tevekkül etmek gerektiği:

"Saklamış olduğun mala ve ilm-i amele güvenmeyip kendini ölmüşlerden sayıp riyazet hamâmında derleyip ve yunup yıkanıp Hakk'a tevekkül üzere olun, deyu tenbih buyurur." (Latife 84) (Halıc1: 2017: 67)

Kaynak: "Ey iman edenler! (Biliniz ki), hahamlardan ve rahiplerden birçoğu insanların mallarını haksız yollardan yerler ve (insanları) Allah yolundan engellerler. Altın ve gümüşü yığıp da onları onları Allah yolunda harcamayanlar yok mu, işte onlara elem verici bir azabı müjdele." (Tevbe suresi, 34. ayet) (Türkiye Diyanet Vakfı Kur'ân-1 Kerîm Açıklamalı Meâli, 2013: 180)

“Mü'minler ancak, Allah anıldığı zaman yürekleri titreyen, kendilerine Allah'ın âyetleri okunduğunda imanlarını artıran ve yalnız Rablerine dayanıp güvenen kimselerdir." (Enfâl suresi, 2. ayet) (Türkiye Diyanet Vakfı Kur’ân-1 Kerîm Açılamalı Meâli, 2013: 166)

Ahiret için hazırlıklı olunması gerektiği:

"Ed-dünyâ mezrâat-ül-âhire mısdâkınca azığını al gideceğin yol yokuştur. Uzun uzak yola gideceksin, ahiret azığı dünyadan gider. Aklını başına topla yolda harami vardır. Gûşiş üzere olup makam-1 âlîye varılacak, elin dolu olsun, boş olmasın kendine himmetin 'âlî olsun, demeği tefhim eder." (Latife 92) (Halıc1: 2017: 71)

Kaynak: "Ey iman edenler! Allah'tan korkun ve herkes, yarına ne hazırladığına baksın. Allah'tan korkun, çünkü Allah, yaptıklarınızdan haberdardır.” (Haşr suresi, 18. ayet) (Türkiye Diyanet Vakfı Kur'ân-1 Kerîm Açıklamalı Meâli, 2013: 546) 


\section{Herkesin ameliyle haşrolacağı gerçeği:}

"Armağan olan kimse pek sevilir. Ben falan âdemim benim falan ceddimdir, falan komşularımdır demeklik ahiretçe fayda vermez. Sonra eliniz boşa çıkar. Herkes ameliyle haşrolacak. Cenâb-1 Kibriyâ’ya kulluk edin tehî-dest olarak huzur-1 Kibriyâya gitmeyin, demeği tefhim eder." (Latife 93) (Halıc1: 2017: 72)

Kaynak: “Allah’a döndürüleceğiniz, sonra da herkese hak ettiğinin eksiksiz verileceği ve kimsenin haksızlığa uğratılmayacağı bir günden sakının.” (Bakara suresi, 281. ayet) (Türkiye Diyanet Vakfı Kur'ân-1 Kerîm Açıklamalı Meâli, 2013: 46)

Sadaka isteyen fakirlere iyi davranılması gerektiği:

"Bir fakir sadaka istedikte rıfk ile muamele edip it'âb ve hitap etmemeli. Kezalik Cenâb-1 Kibriyâ'dan hacetinizi talep ettikte tevazuane talep edip ihsana ve atâyâya şayeste olmalı, demeği tefhim eder." (Latife 109) (Halıc1: 2017: 82)

Kaynak: “Ey iman edenler! Allah'a ve ahiret gününe inanmadığı halde malını gösteriş için harcayan kimse gibi, başa kakmak ve incitmek suretiyle, yapığınız hayırlarınızı boşa çıkarmayın. Böylesinin durumu, üzerinde biraz toprak bulunan düz kayaya benzer ki, sağanak bir yağmur isabet etmiș de onu çıplak pürüzsüz kaya haline getirivermiştir. Bunlar kazandıklarından hiçbir şeye sahip olmazlar. Allah, kâfirleri doğru yola iletmez." (Bakara suresi, 264. ayet) (Türkiye Diyanet Vakfı Kur’ân-1 Kerîm Açılamalı Meâli, 2013: 46)

\section{Kaynağı Dinî Öğretiler Olanlar}

Bilgi ile amel etmek:

"Ki siz hakayıkı müdriksiniz niçin bildiginiz ile âmil olmazsınız. Ben ne söylesem tesir etmeyecek." (Latife 1) (Halıc1: 2017: 8-9)

Övünç elbisesinden soyunmak boyna kefen elbisesini takmak:

"Elbise-i fahireden soyunup kefeninizi boynunuza takıp" (Latife 6) (Halıcı: 2017: 12)

Helal ve haram demeden mal toplamanın ve ahireti düşünmemenin fenalĭgr:

"Zill-ı hayal gibi olan dünyada bilâ tefekkür emta ve erzak toplayıp helâl ve haram demeyip iddihar ve tûl-i emel ile ferdayı düşünmeyen kimselerin yarın bağban-1 hakiki olan Cenâb-1 Kibriyâ divanında öyle eğri büğrü sözler kabul olunmayacağından” (Latife 7) (Halıcı: 2017: 13)

Amele güvenmenin körlük olduğu:

“Geçerken amelimize güvendiğimiz ayn-1 âmâlık olup” (Latife 14) (Halıcı: 2017: 17)

Allah katında makbul olmayan ameller yapılmaması gerektiği:

"Fi zamanına mürâ̂ olan kimselerin abdesti ve namazı indallah makbul olmayıp buna döner, Mürailikle olmayıp lillah fi'llah olunuz ki sa'yiniz hesaba gitmeyip itaba müstahak olmayın deyu, tenbih buyururlar." (Latife 21) (Halıc1: 2017: 21-22)

Dünyayı ve fani dünya hayatını talep eden kimselerin sonunda fesada uğrayacakları gerçeği:

"Dünya talibleri olan kimseler hırs u tama ile gece ve gündüz seğirtip celb-i dünya için esfel tarafına gider. Bu gidişten geçip bir faidemend olacaḳ ve kendisinden zad-1 ahiret doğacak bir 'âlî makama terakki edip darında said olun deyu, tenbih-i âlîleri olmuş ola." (Latife 29) (Halıcı: 2017: 26) 
Dünyanın geçiciliği ve dünya malı için endişe edilmemesi gerektiği:

"Dünya malı için keder etmeyiniz. Bir şeyiniz zayi olursa Cenâb-1 Kibriyầya iltica edin. Mükâfât olunursunuz. Cevāmi` ve mescidlerde mu'tekif olduğunuz halde rica ve niyaz edersiniz. Bu dünya ve mafiha muradatınıza nail olunursunuz. Bu dünya payidâr değildir." (Latife 33) (Halıcı: 2017: 29-30)

Nefis ve şeytanın hilelerinden Allah'a sığınmak:

"Meşhur köpeğe dalınmadan çalıyı dolanmak yeğdir. Nefs ü şeytan ve vesvese-i akran vesâir husemâ galebe çalacak olduklarından "innallahe ma'as-sâbirin deyip Cenâb-1 Kibriyâ'ya sığınıp onlardan intikam alacağım deyu sür'at etmeyip Hudâ'ya ismarlamak evlâ olduğunu imâ buyurur." (Latife 35) (Halıc1: 2017: 31)

Manevi ilimler ve kelamlarla meşgul olmak gerektiği:

"İnsan kendüye ettiğin kimse kimseye edemez. Hemen gûş-i zâhirini yalan ve kerih avaz dinlemeden kes gûş-i bâtının küşad edip manevî kelâmlar istimâ ile baştan dahi geçip küşûfât-1 gaybiyyeye nail olun bir tenha yerde mu'tekif olduğunuz halde Cenâb-1 Kibriyâ'dan yardım talep eyleyip öyle hilâfına iftira etmen, deyu tenbih buyururlar." (Latife 72) (Halıcı: 2017: 59)

Gece ve gündüz gaflet ile vakit geçirilmemesi gerektiği hem vakit hem de ilim peşinde olan hırsızlardan uzak durulması gerektiği:

"Geceleri ta be sabah yatup uyumayın ve gündüz gaflet ile vakit geçirmeyin. Hırsızlar etrafınızı almış görünmezler. Bir gün ayın ışığından iner gibi inip sizin han ü malınızı harab ederler. Ve ibadat ve ta'âtınızı yağma ederler ve malını itlâf ederler. Aklınızı başınıza alıp ed'iye ve ezkâr ile daim ol mevt peşindedir. Hem zaddır ba'del-mevt kabirde çok yatırsın, demeyi tefhim eder." (Latife 77) (Halıc1: 2017: 62-63)

Gece ibadetinin önemi ve fazileti:

"Yeşil gök ile yeşil yer arasında temekkün ediyoruz ve tazyî-i evkat ediyoruz. Yarın kara tavuk şekli olan karanlık kabir içine gireceğiz. Acaba varacağımız kızıl burunlu kırmızı cehennem ateşi midir? Yoksa hal nice olur deyü nısf-ül-leylde kalkıp kalbinde bir çerağ uyandırıp bir saat olsun ibadet ve ta 'ât ile tefekkür etmeli. Zira tefekkürütâate hayr min ibâdet-i seb'iyan sene buyurulmuş, demeyi tefhim eder." (Latife 81) (Halıc1: 2017: 65)

Günahlardan dolayı pişman olunması gerektiği:

"Günahlarınızı önünüze koyup niçin bu günahları işledik deyu ağlamağa doymayıp nedamet ve huzur ile istiğfâr ederek ağlamağa doymayın, demeyi tefhim eder.” (Latife 82) (Halıcı: 2017: 66)

Namaz ve abdestin düzgün alınması gerektiği:

"Abdestinizi dürüst alın ve namazınızı dürüst kılın. Böyle abdest böyle namaz ile huzur-1 ilâhiye durulmaz. Yarın kıyamet günü saf-be-saf olup Sırattan len, olduğunuz halde geçemezsiniz, deyu tenbih buyururlar ki, derûnun ve bîrûnun gill u gişta pak edip rızaya muvafik olmalı, demeyi tefhim eder." (Latife 99) (Halıc1: 2017: 75)

\section{Kaynağı Ahlakî Öğretiler Olanlar}

İnsanların kusurların yüzlerine vurmanın ne kadar kötü bir haslet olduğunun Allah'ın Settaru'luyub ismini örnek gösterilerek anlatılmast:

"Mümin karındaşlarınızın aybını bâ-husûs ihtiyaçlı olan kimselerin aybını yüzlerine vurup şermsâr u hacil etmeden ise ona nasihat ve redd-i leyyin ile kendisini hoşnud eylemenin tarikinde 
bulunup ilerüde kendiniz vesirleri mutazarrır olmamanın tarikini ihtiyar ile settâr-ül-uyûb olan Cenâb-1 Kibriyâ'dan ecr-i azim taleb olunması lüzumunu tarif buyururlar." (Latife 16) (Halıcı: 2017: 18)

"Dil bir, kulak ikidir" mefhumunca konuşmaktan çok dinlemek gerektiği:

"Dil bir kulak ikidir. Az söyleyip çok dinlemeli. Zira beyhude söz söylemenin mazarratı çoktur. Akil olan tekellüm etmez. İlla hacet vakti tekellüm eder deyu, tenbih buyururlar." (Latife 17) (Halıc1: 2017: 19)

Halkın malına onun izni olmaksızın dadanmamak gerektiği, bunun cezasının ahirette yahut bir tarikata girildiği takdirde orada verileceği:

"Öyle bilâ-destur öküz gibi halkın hanesine ve bağ u bostanına sahibinin izni olmaksızın girerseniz eğerçi arz-1 dünyada sopayı yemezseniz şeriat ve tarikat arabasına koşuldukta yahut yarın ruz-1 kıyamette Zebaniler sizi araba gibi sürüyerek darb-1 şedid ile döverler. Meğer bir Şâfîin şefaatiyle halâs bulunca çok sopa yersiniz demeyi tarif buyururlar." (Latife 20) (Halıcı: 2017: 21)

Kötülerle ahbaplık edilmemesi gerektiği:

"Kişi mukarininin hükmünü alır. Eğerçi iyi kimselerle mukarin olursan misk ve amber bulaşır. Kötü kimselerle yâr olursan kötülüklerinden sana da akseder. Kötülerle yâr olma, iyilerden iyilik öğren, demeği tefhim eder." (Latife 97) (Halıc1: 2017: 74)

\section{Kaynağı Tasavvuf Olanlar}

Amel ile gururlanmayı şeriat ve tarikat yoluna girmek:

"Amelim var deyu güvenme ve gurur dahi etme. Berhayat iken bu dünyada şeriat ve tarikat hamamında yıkanıp riyazet ve perhizat ve amel-i salih ile fikr-i bekaya hasr-1 vakt ederek tevhid ve tehlil ile 'âlî makamlarda nağme ve terennüm ve müşahede-i cemalullahiye tergỉb buyururlar." (Latife 4) (Halıc1: 2017: 11)

Masiva ve akçenin değersizlĭgi:

"Bu fani dünyada ellerimizde bulunan akçe ve masiva ayn-1 rüya gibidir." (Latife 5) (Halıcı: 2017: 11)

Konya'nın evliya diyarı oluşu ve Mevlevilik:

"Konya makarr-1 evliyadır. Helva gibi olan sülûkı darb u terbiye ile yedürürler. Bâhusûs dergâh-1 Hazret-i Mevlânâ'ya dahil olanlara tarab u semâ‘ ile irşâd edip lokmasın dahi terbiye ile tegaddi ederler demeği tefhim buyururlar." (Latife 8) (Halıc1: 2017: 13-14)

Nefis mücadelesi:

"Nefsiniz devesine tedric ile binün aman verip kükretmeyin. Zira mesa gösterirseniz sizi kükreyip altına alır, helâk eyler. Ol size galebe etmeden himye ve cû' ile anı zebh ederek ruhunuzu nefsiniz üzerine galebe ettirüp menzil-i makșud olan Cenâb-ı Kibriyâ’ya vasıl olun, demeyi tefhĩm eder. Nefisle mücahede düşman ile muharebeden ekberdir deyu tenbih ve tekid buyururlar." (Latife 11) (Halıc1: 2017: 15)

\section{Kemal sahibi bir insana intisap edilmesi gerektiği:}

"Yarın rûz-1 mahşerde saf-be-saf durulup sual olundukta mes'ûller dahi şurût-1 İslâm'ın ve kitabın mugayiri nasihat eden imamları tutup mahşer halkı arasında rüsvay olmadan ise şimdiden şeriatın ve tarikatın imam-1 kâmilini bulup ulu dĩvanda şerm-sar u hacil ve rüsvay olunmaklıkdan hazer olunmasını tenbih buyururlar." (Latife 13) (Halıc1: 2017: 16-17) 
Bir tarikata ve mürşid-i kâmile intisap etmek:

"Bir dergâha ve mürşid-i kâmile intisab edip şeriat ve hakikat ve marifet hicablarını ref" ederek bağbân-1 hakîkiye vâsıl oldukta olduḳda nâz-1 niyazda bulunup sizlere itab ve hitab olursa dahi ayn-1 inayet olup bağban-1 hakikate vâsılinden olmaklı̆̆ı tarîf ve işaret buyururlar." (Latife 18) (Halıc1: 2017: 19-20)

\section{Dünyanın köhneliği, faniliği:}

"Bu fani olan dünyaya bekâsı var gibi cülûs ile bir gün bir gecelik ömrü tükenmez zannedip şar u şer ile vakit geçirmeyin. Bir gün Azrail aleyhisselam kapıya gelip ciyfe-i dünyadan alıp kaldırmak ister. Bu bekâsı olmayan âb-1 rîz gibi olan dünyayı bakî sanman, bekaya muhabbet birle çıkın deyu, tenbih buyururlar." (Latife 23) (Halıc1: 2017: 23)

Tarikata ve halvete girdikten sonra bu yoldan dönülmemesi gerektiği:

“Tarîk-i Hakk’a girip girip sülûkundan ve halvete dühûlünden sonra öyle avdet edip dönmiyesin. An be an terakki edip Cenâb-1 Hakk'a vâsıl olun deyu tenbih-i 'âlîleri olmuştur." (Latife 26) (Halıcı: 2017: 24)

\section{Nefse hizmet edilmemesi gerektiği:}

"Şu halde nefsinize hizmet etmeyip mahkûm edin deyu, tenbih ederler." (Latife 30) (Halıc1: 2017: 27)

\section{Tasavvufun ilim olarak öğrenilmesi gerektiği:}

"Tașavvuf lübbdür. Sûrî manevî menafi-i kesire ile fâide-mend olursunuz, demekdir." (Latife 32) (Halıc1: 2017: 29)

\section{Masiva hevesine düşülmemesi gerektiği:}

"Masivâya itimat etmeyiniz. Vadeniz tamam oldukta erzakınızı alıp götürürler Kendinizi yüksek sala koyup mezar başına götürürler. Ol vakit kendinizin ne olduğunu tanırsınız. Bu dünya çaylağa benzer arkasına düşmen başınızın kaygısına bakın, demeği tefhim eder." (Latife 39) (Halıcı: 2017: 34)

\section{Masivayı terk edip Allah ile ünsiyet kurulması gerektiği:}

"İte dalanmadan çalıyı dolanması yeğdir. Terk-i masivâ birle uzlet ihtiyar et. Zira şeytan imana, Azrail cana, varisler kavga ile mala dolaşırlar. Eğerçi bunlara mutabaat ederseniz, seni maldan candan ettiklerinden başka eliyazü bi'llah sevgili imandan dahi eder, deyu tenbih buyururlar." (Latife 73) (Halıc1: 2017: 60)

Cihâd-ı ekber ve cihâd-ı asgar:

"Cihad-1 ekber ve cihad-1 asgarda çok zahmet çekiliyorsa da muharebe ve mücadele eyle; ardınca ecr-i cezîllere nail olunur. Zira gerek cihad-1 ekberde ve gerek cihad-ı asgarda çok akâbeler vardır. Onlara tahammül sebebiyle Cenâb-1 Kibriyâ nice müjdeler beyan eylemiştir. Cihada hazır olun, deyu tenbih buyururlar." (Latife 78) (Halıc1: 2017: 63-64)

\section{Masiva muhabbetinde olmamak gerektiği:}

"Hane-i vücudunuzda gıll ü gışş masivâ muhabbetini mahvedin ve yerine iman ve irfan dolsun. Şeytan geldiği halde nûr-1 imandan gayri bir şey bulamayıp tehi-dest olarak gider nûr-1 iman yedekte kalır demeği tarif buyururlar.” (Latife 79) (Halıc1: 2017: 64) 
İnsanın iç temizliğe önem vermesi gerektiği:

"Bu fâni dünyaya câme-şûyluğa gelmedin, ne kadar yıkasan yine kirlenir câme-şûyluktan cansûyluk yeğdir. Dışımızı yıkamadan ise derunumuz pasını yıkayalım, demeği tefhim eder." (Latife 85) (Halıc1: 2017: 67)

Dünya malına tamah etmemek, Hak rızasına ve vahdet sırrına erişmek:

"Dünya ve mafihâyı bir pula alma mir'at-ı kalbine nazar edip canını ve başını rızâullaha feda ile ser verip sır vermeyenlerle olup sirrı vahdet bulup rızaya mazhar ol demeği tefhim eder" (Latife 90) (Halıc1: 2017: 70)

"Sen ben" demeyi ortadan kaldırmak, vahdet sırrına nail olmak (vahdet-i vücûd):

"Sen bir katresin. Kendini deryaya sal mütabahhirinden ol ki, ol vakit sen de deryâ-dil olup sırr-1 vahdete nail olursun. Şimdiden kemend-i aşk boynuna takıp ben sen demeği aradan kaldır." (Latife 91) (Halıc1: 2017: 70)

Muallim ve mürşid önünde edep ve erkâna dikkat edilmesi gerektiği:

"Muallim ve mürşid huzurunda çağırıp bağırana hemen dersinle devrinle âdâb ve erkân öğrenir isen bir büyük işde kullanırlar deyü tenbih eder.” (Latife 94) (Halıcı: 2017: 72)

Kesrette vahdeti bulmak:

"Daire-i vahdete nail olanın sağı solu olmaz. Leb-â-leb derya gibi dolar terk-i masivâ birle sırr-1 vahdete nail olur. Meselâ bir çöpün ucunu yakıp döndürsen bir noktadan kebir daire olur. Kesrette vahdeti bulun, deyi tenbih buyururlar." (Latife 100) (Halıc1: 2017: 76)

Şeriat ve tarikat yolunun bırakılmaması gerektiği:

"Şeriat-1 garra bir tarîk-i âmdır ve bir deryâ-yı muhittir ki nice murdarları tathir eder. Şeriat-1 garraya temessük edin zinhâr şeriat ve tarikat yolun bırakmayınız. Zahir ve batınınızı pek eder, deyu tarif buyururlar." (Latife 103) (Halıc1: 2017: 78)

İnsân-ı kâmilin özellikleri:

"İnsan mah-1 hilâl gibi zuhur edip insan-1 kâmil oldukta âlem ziyasiyle sâye-mend olduktan sonra vücud pîr-i fani oldukta yine hilâl gibi kalırsa da rûh-1 şimşir-i Hüdâdır ten gılaf olmuş ana dahi alakadar eder bir tığı kim üryan ola mefhumunca ol insan-1 kâmilin ruhu şimşek ve yıldırım demirinden ziyade parlar. Rûhaniyet-i 'âlileri âleme ziya verir. Ruhanî istimdâd ederler, demeği tefhim eder." (Latife 105) (Halıc1: 2017: 79)

Maddi anlamdaki şarabı bırakıp manevi yani ilahi aşk şarabını içmek gerektiği:

"Bir katresi haram olmuş, şarap içenler bî-hodluk âlemine varayım deyu zahir aklı çok olup birazı gitsin deyu olmalı şu bâbda hem malını, hem namusunu hem vücudunu verir. Eğer bî-hodluk âlemini bulayım dersen hem maldan hem namustan olma. Yalnız vücudunu feda eyleyip say eylemekle şarab-1 ezelinden nûş edip hakikaten bî-hodluk âlemini bulup aşkullah ile vasıl-1 deryayı hakikate kadem bas, demeyi tarif buyururlar." (Latife 116) (Halıc1: 2017: 86-87)

\section{Sonuç}

Türk halkının hafızasında fikralarıyla önemli bir yer tutan Nasreddin Hoca, çağlar boyunca hem Türk kültürü için hem de evrensel kültür için çok önemli bir isim olmuştur. Bu sebeple de fikraları çok fazla yaygınlık kazanmış ve bunlar üzerine yazılar yazılmıştır. Bahsi geçen yazılardan bazıları da fikralar üzerine yapılan şerhlerdir. Bilindiği üzere şerhlerin belli hususlarda bir çıkış noktası olabilir, tasavvufî ve dinî nazar da bunlardan biridir. Şair Burhâneddin, Nasreddin Hoca'nın 
fikralarını şerh ettiği eserinde işte bu noktadan yani tasavvuftan ve dinî mefhumlardan yola çıkmıştır. Şair, önce Hoca'nın fikralarını anlatmış ardından bunları hep bir dinî veya tasavvufî̀ kisveye bürümüştür. Bu, kimi zaman isabetli ve tutarlı olurken kimi zaman da zorlama olmuştur. İki tutum da bize şârihin Nasreddin Hoca'nın her fikrasında bir hikmet ve tasavvufla örülü bir arka plan olduğunu düşündügünü göstermektedir. Şair Burhaneddin'in bu tutumundan dolayı onun eserini dinî ve tasavvufî bakımdan incelemek mümkün olmuştur.

İncelememiz neticesinde şerhlerdeki açıklamaların birtakım dayanak noktalarının olduğu tespit edilmiştir. Bunlar; hadis veya hadis olduğu rivayet edilen sözler, Kur’an-1 Kerim, tasavvuf ve dinîahlâkî öğretilerdir. Çalışmamızda eserde bulunan ifadeler bu kaynak noktalarına göre sınıflandırılmış, tasnif neticesinde tasavvufun bu kaynaklar arasında sayıca ön plana geçtiği tespit edilmiştir. Bu çalışma ile insanlık mirası için önemli bir isim olan Nasreddin Hoca'nın fikralarının tasavvufî bakış açısıyla nasıl açıklandığı, bunları yaparken şârihin üslubunun, tutumunun ve kaynaklarının neler olduğu ortaya konulmuştur. Bu sayede evrensel kültür belleğindeki önemli bir ismin fikralarına farklı bir nazardan bakılmaya çalışılmıştır. Bunun dışında çalışmanın sonunda eserde geçen tasavvufî terimlerin bir listesi verilmiştir. (4)

\section{Kaynakça}

Aksoyak, İsmail Hakkı. Söylenmemiş Sözler. Ankara: Grafiker Yayınları, 2016.

Albayrak, Nurettin. "Nasreddin Hoca maddesi" Türkiye Diyanet Vakfı İslam Ansiklopedisi. 2006, s. $418-420$.

Güzel, Abdurrahman. Dinî-Tasavvufî̀ Türk Edebiyatı El Kitabı. Ankara: Akçağ Yayınları, 2012.

Halıcı, Feyzi. Şair Burhâneddin'in Nasreddin Hoca'nın Fıkralarını Şerh Eden Eseri. Ankara: Atatürk Kültür Merkezi Başkanlığı, 2017.

Hayrettin Karaman ve diğer. Kur'ân-ı Kerîm Açıklamalı Meâli. Ankara: Türkiye Diyanet Vakfı Yayınları, 2013.

Türkmen, Fikret. Seyyid Burhaneddin Çelebi Letâif-i Nasreddin Hoca Nasreddin Hoca Latifeleri (Burhaniye Tercümesi) İnceleme-Şerh. İstanbul: Büyüyenay Yayınları, 2013.

Özdemir, Nebi. "Mizah, Eleştirel Düşünce ve Bilgelik: Nasreddin Hoca”, Milli Folklor 87, (Güz 2010): 27-40.

Uludağ, Süleyman. Tasavvuf Terimleri Sözlüğ̈̈. İstanbul: Kabalcı Yayıncılık, 2012.

http://www.tdk.org.tr/index.php?option=com tarama\&view=tarama

Erişim Tarihi: 20.01.2019

http://www.lugatim.com/

Erişim Tarihi: 15.01 .201

\section{Notlar}

1. Kaynağının hadis veya hadis olduğu rivayet edilen sözler olduğu belirlenen kullanımlarda Diyanet İşleri Başkanlığı tarafından elektronik ortamda kullanıma açılan Hadislerle İslam eserinden faydalanılmıştır.

https://hadislerleislam.diyanet.gov.tr/

2. https://hadislerleislam.diyanet.gov.tr/ 
3. Kur'an-1 Kerim meâli için atıf yapılan eser dışında Diyanet İşleri Başkanlığı’nın elektronik ortamda erişime açtığı mealden de faydalanılmıştır.

https://kuran.diyanet.gov.tr/

4. Eserde kullanıldığı tespit edilen tasavvufî terimler şunlardır:

Bağbân-ı hakîka: Hakikat bahçesinin bahçıvanı; Allah.

Bekâya muhabbet: Bekabillâha, baki olan Allah ile ebedî olmaya duyulan muhabbet.

Beyne'l-havf u recâda bulunmak: Kulun daima korku ile ümit arasında bulunması.

Cân-şûyluk: Ruhu maddi kirlerden, bedenî isteklerden arındırma.

Cihâd-ı ekber: Büyük savaş; nefisle mücadele.

Cihâd-ı asgar: Küçük savaş; meydanlarda yapılan gerçek nitelikteki mücadele.

Derviş: Tarikata girip bir mürşide bağlanan, tasavvuf yolunda ilerlemeye gayret eden kişi.

Dünyâ ve mâfihâ: Dünya ile masiva.

Dünyâ țâlibleri: Esas dünya olan ahireti değil de fani olan dünyayı önemseyen, onun nimetlerine talip olanlar.

Ehl-i hâl: Diliyle, sözüyle değil gerçek manada hâl ile tasavvufa girmiş olan kişi; tasavvuf ehli.

Elbise-i fâhireden soyunmak: Övünç elbisesinden soyunmak; insanın gururdan, övünülmekten dolayı duyulan hazdan kendini geri koyması, bunun peşinde olmaması.

Esb-i himmete binmek: Himmet atına binmek; Allah yoluna girmek.

Etfâl-i tarîkat: Tarikat çocukları; tarikata yeni giren sâlikler.

Halvet: Sufinin mâsivâdan, nefsî arzularından uzaklaşması ve Allah'la bir olması.

Harâmî: Kulu Hak yoldan çevirmeye çalışan kişiler.

Hevâyı terk etmek: Dünyalık hevesleri, endişeleri terk edip Allah yoluna girmek.

İnsân-ı kâmil: Tasavvufta en üst mertebelere erişmiş mürşit, şeyh.

İşâd etmek: Allah yoluna davet etmek.

Kesret: Vahdetin zıddı; çokluk. Allah'ın birliği vahdeti, yaratılmışların çokluğu ise kesreti ifade eder.

Lokma: Dervişane yaşamın temel felsefelerinden olan "Bir lokma bir hırka" anlayışının ifade edilme biçimi.

Mâsivâ: Kulu doğru ve ebedi yoldan ayıran, Allah ve Allah bilgisi dışındaki her şey.

Mâsivâ muhabbeti: Masivaya duyulan sevgi.

Marifet: Tasavvufun dört ana kapısından biridir. Mevcudatın varlı̆̆ını tasavvuf yolunda olanlara has bir biçimdeki ilahi kaynaklı sezgilerle bilmek anlamına gelir.

Menzil-i maksûd: Ulaşılmak istenen esas menzil olan yüce Allah.

Murdar: Şeriat yolunda olmayan kişi.

Mücâhede: Nefisle cihat halinde olmak, onunla mücadele etme. 
Mürşid-i kâmil: Tasavvufa yoluna girmeleri için sâliklere irşat faaliyetinde bulunan tarikat büyügü.

Müşâhede-i cemâlullah: Allah'ın cemalini müşahede etme, görme; rüyetullah, manevi sırlara kalp gözüyle görmek suretiyle nail olma.

Nazar etmek: Şeyhlerin ilahi nur ile mürşitlerine bakması, onları bu yolla eğitmesi.

Nefis devesi: Nefsin deveye benzetilmesi suretiyle oluşmuş terim.

Nefis kanatlarını kesmek: Kulun kendini nefsin hoşlandığı işlerden sakınması.

Nefsi kükretmek: Nefsi beslemek, onun istediklerini yerine getirmek.

Perhîzât: Dünyevi işlerden, heva ve heveslerden kendini sakınma, geri çekme.

Râh-ı hakîkate vâsıl olmak: Hakikat yoluna ulaşmak; tasavvuftaki hakikat mertebesine erişmek.

Rızâ: Kulun başına gelen iyi ya da kötü her şeyden memnun olması; üzüntüsünde de sevincinde de aşırıya gitmemesi.

Rızâullah: Allah'ın rızası, O'nun rızasına uygun hal ve tavırda olma durumu.

Riyâzet: Nefis terbiyesi için az yemek, az içmek, az uyumak. Nefsin hoşlandığı işlerden uzak durma.

Riyâzet arabasına süvâr olmak: Riyazet arabasına binmek; riyazet üzere yaşamaya başlamak.

Riyâzet hamâmına girmek: Riyazete başlamak, riyazet yoluna girmek.

Sâlik olmak: Bir tarikata girip mürşide intisap etmek; seyr ü sülûk yoluna girmek.

Sirr-ı vahdet: Vahdet sırrı; Allah'ın bir olduğu inancına dair ilahi gizlilik.

Sülûk: Bir tarikata girip şeyhe intisap ederek manevî yolda ilerleme.

Şarâb-ı ezelî: Ezeli şarap; ilahi aşk şarabı.

Şehevât-ı nefsâniyye: Nefsin şehevi arzuları.

Şeriat ve tarîkat arabasına koşulmak: Şeriat ve tarikat yoluna girmek.

Şeriat ve tarikat hamâmında yıkanmak: Şeriat ve tarikat yoluna girip o yolda ilerlemek; şeriat ve tarikatın öğretileriyle hemhal olmak.

Terk-i mâsivâ: Masivayı terk etme; kulun Allah dışında kalan her şeyden alakasını kesmesi.

Tevhid: Allah'ın birliği inancı.

Uzlet: Halkın içinde halkla olma.

Vahdet-i vücĥd: Varlığın birliği; yaratılmış olan her şeyin esas varlık olan Allah'ın âlemdeki zuhuru, tecellisi olduğu inanci.

Vâsıl-ı deryâ-yı hakîkat: Hakikat denizine ulaşma; tasavvufun hakikat derecesine varma. 